\title{
Social Cognition in Schizophrenia: A Review Study
}

\author{
Neama Kamel $^{1 *}$, Fryial AlQahtani ${ }^{2}$ \\ ${ }^{1}$ Department of Community Nursing, Psychiatric Nursing Specialty, College of Nursing, Imam Abdulrahman Bin Faisal \\ University, Dammam, KSA \\ ${ }^{2}$ Department of Community Nursing Care, College of Nursing, Imam Abdulrahman Bin Faisal University, Dammam, KSA \\ Email: ^nmkamel@iau.edu.sa, *neamafouad@yahoo.com
}

How to cite this paper: Kamel, N. and AlQahtani, F. (2019) Social Cognition in Schizophrenia: A Review Study. Open Journal of Psychiatry, 9, 81-97. https://doi.org/10.4236/ojpsych.2019.92007

Received: January 24, 2019

Accepted: March 1, 2019

Published: March 4, 2019

Copyright (C) 2019 by author(s) and Scientific Research Publishing Inc. This work is licensed under the Creative Commons Attribution-NonCommercial International License (CC BY-NC 4.0) http://creativecommons.org/licenses/by-nc/4.0/ cc) (i) (8) Open Access

\begin{abstract}
Social cognition includes all operations encountered in the process of perceiving, understanding \& production of appropriate reactions while confronting with others. These include: social awareness, theory of mind, attributive style, and emotion processing. Social cognition skills have been recognized as a vital component in the rehabilitation process for schizophrenic persons, its strong contributors in social function among individual suffering from schizophrenia. The purpose of this review is to appraise various researches about social cognition and its correlates in addition to evaluating various cognitive interventions targeted toward improving social cognition function among patients group and to find the best techniques to ameliorate social cognitive deficits in schizophrenia. Databases were searched from the period from the year 2000 to October 2018. The search terms used were "Social cognition", emotional management program, schizophrenia. A total of 85 articles were identified and those who meet inclusion criteria including 27 articles. Finding indicates the efficacy of social intervention that targets cognitive aspect in functional abilities of schizophrenic patients and also emotion processing which are significant mediators of social performance aptitudes in patients group.
\end{abstract}

\section{Keywords}

Social Cognition or Social Cognitive Training (SCT), Emotional Management Program or Training and Schizophrenia

\section{Introduction}

Social cognition (SC) is a mental assembles which includes all operations encountered in the process of perceiving, understanding \& production of appropriate reactions while confronting with others. The amounts of elements in- 
cluded in social cognition domain are varied but in general it ranges from 3 to 5 areas. These include: social awareness, theory of mind, attributive style, and emotion processing. Social awareness means making inferences about social situations in a specific social circumstances \& applying this knowledge, comprehension in producing suitable response; while theory of mind (ToM) is related to the talents of understanding, comprehension of other's thoughts, opinions, intuitions \& to differentiate between it and one's own; attributive style (AS), which is concerned with how people tend to attribute and explain causes of situations that they are encounter in their life either caused by the misconduct of others or by themselves and lastly emotion processing which concerned with recognizing of different emotions, expressions and management process [1] [2].

Social cognition skills have been recognized as a vital component in the rehabilitation process for schizophrenic persons, its strong contributors in social function among individual suffering from schizophrenia [3] [4]. The purpose of this review is to appraise various researches about social cognition and its correlates in addition to evaluating various cognitive interventions targeted toward improving social cognition function among patients group and to find the greatest methods to eliminate social cognitive deficits in schizophrenia.

\subsection{Search Strategy (Figure 1)}

Guidelines for preferred reporting items for systematic review were utilized. The following databases were searched: Pub Med, science direct, internet, and Midline from the period from the year 2000 to October 2018. The search terms used were "Social cognition", emotional management program, schizophrenia.

A total of 85 articles were identified and those who meet inclusion criteria including 27 articles.

\subsection{Inclusion Criteria}

We set out the following inclusion criteria:

1) Target group had a diagnosis of schizophrenia.

2) Systematic review was conducted up to May 2018.

3) Focused on empirical study or systematic review.

4) Focused on evidence based intervention program.

5) Focused on recommendation of authenticate source.

\subsection{Exclusion Criteria}

1) Not a peer-reviewed original research article, e.g. commentary, editorial, letter, report, guidelines or conference or meeting proceedings.

2) Not published in English.

\section{Results}

Twenty seven articles have been recognized to meet inclusion criteria were categorized into two parts: 


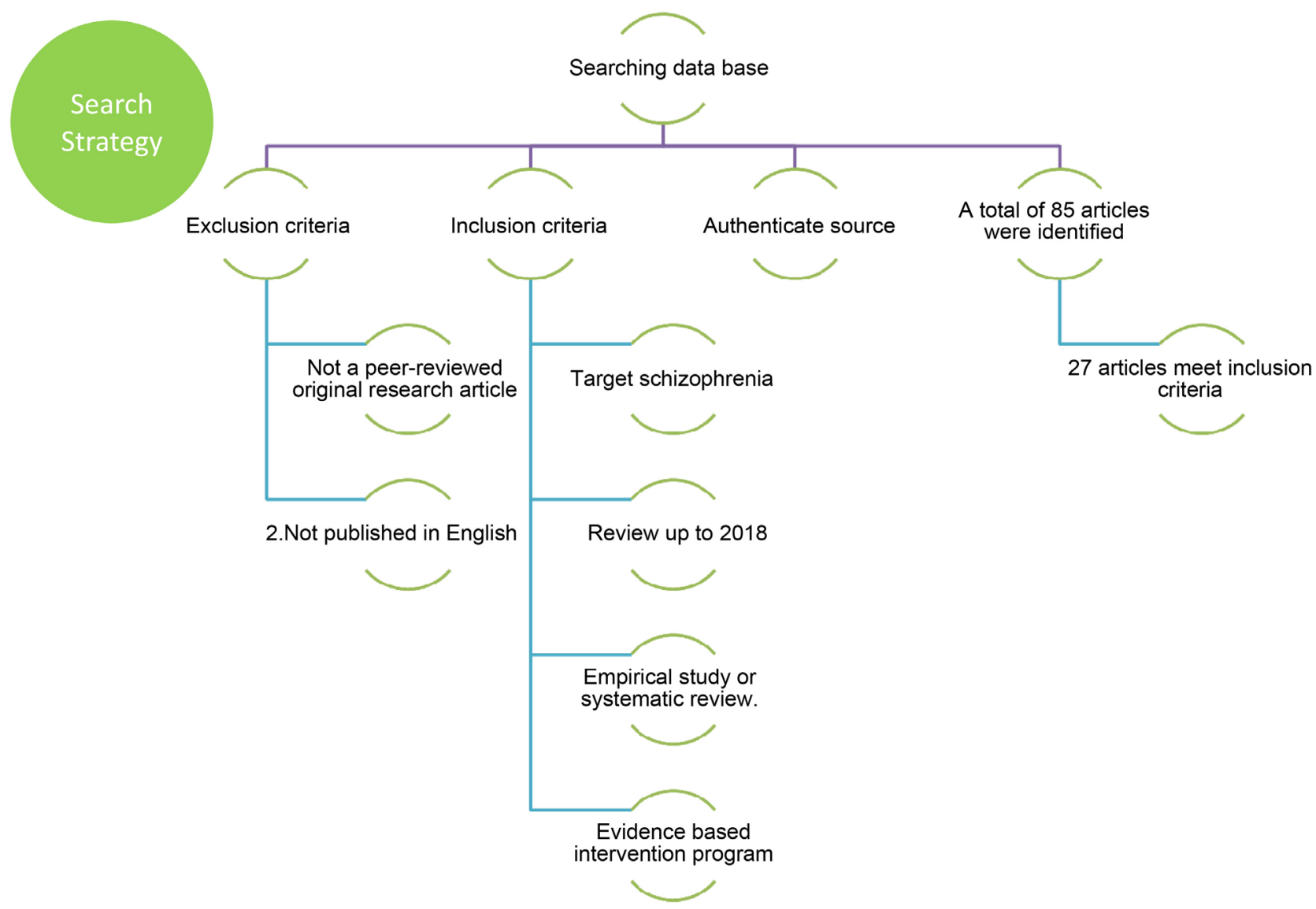

Figure 1. Search strategy.

\section{- PART I: -DESCRIPTIVE STUDIES (Table 1)}

Twelve descriptive studies were drawn to provide data about natures of social cognition deficit, organic origin for social cognition insufficiency in schizophrenic persons and relation between social cognition and social function among schizophrenic patients.

Zhua LX et al. (2013) compare between nearly one hundred schizophrenic patients \& one hundred healthy subjects regarding eye movement while recognizing of different emotions and expression. They found that patients with schizophrenia have limited ability in emotion recognition process especially for negative faces. They attribute this to the presence of -ve symptoms which may influence patient ability in visual scrutinize stricture [5].

Regarding organic origin for social cognition insufficiency in schizophrenic persons; Akara SA et al. (2015) monitor recorded EEG (Electroencephalogram) data to examine neural network in the left fronto-temporal area during emotional processing task [6]. They record EEG in 2 circumstances. First one while latent period and second one during hearing stimulation using white noise. Results indicating the presence of abnormality in the left fronto-temporal area.

While Razafimandimby A et al. (2016) uses Magnetic Resonance Imagine to examine the neural activity under two different conditions. First condition is to 
Table 1. Summary of descriptive studies.

\begin{tabular}{|c|c|c|c|c|c|}
\hline $\begin{array}{l}\text { STUDY } \\
\text { AUTHORS }\end{array}$ & $\begin{array}{l}\text { APPLICATION OF } \\
\text { TREATMENT }\end{array}$ & $\begin{array}{c}\text { INTERFERENCE } \\
\text { METHOD }\end{array}$ & $\begin{array}{l}\text { SAMPLE/ } \\
\text { DESIGN }\end{array}$ & $\begin{array}{l}\text { SIGNIFICANT } \\
\text { FINDING }\end{array}$ & $\begin{array}{c}\text { OTHER } \\
\text { OUTCOMES/NOTES }\end{array}$ \\
\hline $\begin{array}{l}\text { Fiszdon, J. M., } \\
\text { \& Reddy, L. F. } \\
(2012)\end{array}$ & $\begin{array}{l}\text { literature search target } \\
\text { social cognitive } \\
\text { interventions in } \\
\text { schizophrenia }\end{array}$ & $\begin{array}{l}\text { Present data on nearly } \\
\text { fifty researches assess } \\
\text { a variety of social } \\
\text { cognitive interference }\end{array}$ & review study & $\begin{array}{l}\text { A variety of } \\
\text { interference have } \\
\text { been initiated that } \\
\text { aim improving } \\
\text { recognizing } \\
\text { emotions, including } \\
\text { Mind theory, social } \\
\text { awareness, Affect } \\
\text { recognition attempt } \\
\text { have been the most } \\
\text { frequent interference } \\
\text { but there is no } \\
\text { attempt have } \\
\text { specifically } \\
\text { directed to improve } \\
\text { attributional style, } \\
\text { social knowledge, } \\
\text { or emotional } \\
\text { intelligence. }\end{array}$ & $\begin{array}{l}\text { Almost all of the } \\
\text { interferences remained } \\
\text { helpful in enhancing } \\
\text { methods of emotion } \\
\text { recognition, indicative } \\
\text { of that affect awareness } \\
\text { is flexible }\end{array}$ \\
\hline $\begin{array}{l}\text { Vita A et al. } \\
(2018)\end{array}$ & $\begin{array}{l}\text { Reviewed researches } \\
\text { by revising various } \\
\text { pharmacological } \\
\text { cognitive enhancers } \\
\text { supposed to enhance } \\
\text { cognition in } \\
\text { schizophrenia and } \\
\text { mood disorders. }\end{array}$ & $\begin{array}{l}\text { Provide information } \\
\text { on various drugs } \\
\text { targeting } \\
\text { neuroplasticity } \\
\text { improving for } \\
\text { schizophrenia }\end{array}$ & review study & $\begin{array}{l}\text { Medications can } \\
\text { proper modify neuro } \\
\text { chemical } \\
\text { discrepancies that } \\
\text { trigger } \\
\text { neuroplasticity } \\
\text { alterations in the } \\
\text { brain, while cognitive } \\
\text { exercise may } \\
\text { make the creation } \\
\text { of more adaptive } \\
\text { neural } \\
\text { circuits }\end{array}$ & $\begin{array}{l}\text { The future studies } \\
\text { should examine the } \\
\text { durability effects of } \\
\text { enhancing } \\
\text { plasticity-using drugs } \\
\text { alongside with cognitive } \\
\text { teaching to bring the } \\
\text { configuration of more } \\
\text { steady neural circuits }\end{array}$ \\
\hline $\begin{array}{l}\text { Tabak, N. T et } \\
\text { al. (2015) }\end{array}$ & $\begin{array}{l}\text { Examined emotional } \\
\text { Intelligence \& its } \\
\text { relation to clinical and } \\
\text { social factors among } \\
\text { studied groups. Thirty } \\
\text { five schizophrenia or } \\
\text { Bipolar I \& thirty eight } \\
\text { matched } \\
\text { corresponding } \\
\text { group were included }\end{array}$ & $\begin{array}{l}\text { Studied subject in } \\
\text { both groups finished } \\
\text { society performance } \\
\text { and symptom } \\
\text { presentation }\end{array}$ & $\begin{array}{l}\text { descriptive } \\
\text { correlation } \\
\text { design }\end{array}$ & $\begin{array}{l}\text { Results reveal that } \\
\text { both groups show } \\
\text { considerable poorer } \\
\text { perceived emotional } \\
\text { Intelligence } \\
\text { Trait than } \\
\text { corresponding } \\
\text { group, but did not } \\
\text { change from each } \\
\text { other. Higher } \\
\text { emotional } \\
\text { intelligence traits } \\
\text { associated with } \\
\text { elevated levels of } \\
\text { self-governing } \\
\text { living in both } \\
\text { groups. }\end{array}$ & $\begin{array}{l}\text { The results propose that } \\
\text { perceived EI is making } \\
\text { worse and connected to } \\
\text { social performance in } \\
\text { both groups }\end{array}$ \\
\hline
\end{tabular}




\begin{abstract}
55 clients with
schizophrenia, mainly paranoid and fifty five corresponding group applying empathy

Lehmann A et Test (the Multifaceted, al. (2014) Interpersonal Reactivity Index, in addition to the inner experience using Emotional Contagion Scales.
\end{abstract}

Question the manner in which

schizophrenic

Vogel B et al. disorders impact the (2016) patient ability to assimilate both oral expression and others nonverbal cues.
Seventy eight

Ahmeda OH (2018) investigate the relation between aggression

Ahmeda $\mathrm{OH}$ (2018) patients traits \& cognitive impairment taken into consideration how negative emotions affect cognitive deficit
Test the Multifaceted, Interpersonal Reactivity Index, in addition to the inner experience using Emotional Contagion Scales. descriptive correlation design
For this reason Different video shows were offered to twenty one patients versus 21 control subject
Schizophrenic

Persons showed

disturbance in

cognitive empathy,

but have normal

level of emotional

empathy.

They describe considerably extra

harmful emotional contagion,

devastating

emotions, deficiency

in of emotions, and

imagination

capacity, but

fewer self-power

of emotional expression than corresponding group

The studied subject evaluates the effect of the presenter emotional condition on a four-point range as of extremely negative to extremely positive. The relative influence of nonverbal cues as contrast to verbal cues on these ratings was appraised

schizophrenic and schizoaffective

Were employed from a state hospital.

Applicants were classified based on their history of Intense offending.
Patients tend to stand their choice fewer on nonverbal cues and extra on verbal data than corresponding group

aggressive patients displayed larger impairments in the majority cognitive area particularly operational memory \& verbal learning. as well have larger destructive emotionality, agitation, and occurrence of verbal and physical aggression.
It can be expected that elements of emotion handling are important mediators of empathic aptitudes in schizophrenia

It can be assumed that variables of integrative capacity should be considered in management plan
They found that cognitive insufficiency raise the liability of reckless violence in schizophrenia by means of incompetent control of negative emotional condition. 


\section{Continued}

\begin{tabular}{|c|c|}
\hline \multirow{10}{*}{$\begin{array}{l}\text { Akara SA et } \\
\text { al. (2015) }\end{array}$} & Monitor recorded \\
\hline & EEG data to examine \\
\hline & neural network in the \\
\hline & left fronto-temporal \\
\hline & area. They record EEG \\
\hline & in 2 circumstances. \\
\hline & First one while latent \\
\hline & period and second one \\
\hline & during hearing \\
\hline & $\begin{array}{l}\text { stimulation using } \\
\text { white noise }\end{array}$ \\
\hline
\end{tabular}

Literature search target searching the association between

Ferrara AL et emotional processing al. (2012)

ZhuaLX et al. (2013)
To study the original brain mechanism during emotional arousal condition through investigating EEG cues in schizophrenia patients investigated

the association between hallucination and emotional prosody understanding in have stayed inspected among schizophrenic patients
Examined eye behavior changes throughout facial emotion recognition involving one hundred schizophrenic clients versus one hundred corresponding group.
Results indicating the presence of abnormality in the left fronto-temporal area. where by minor values at the left frontal (L1), parietal and right central regions throughout entire process contrast to corresponding group who have a considerably elevated D2 merely in the F3 and the $\mathrm{P} 4$ area through the CTM practice

Results of researches are contrary. a number of inquiries did not discover a relation involving emotional process deficits \&

hallucinations. While others indicate presence of relation

Considerably extra straight fixations that long-lasting to noticed areas such as the mouth, eyes, nose, The sum fixation numeral, duration, and whole duration were considerably augmented in schizophrenia.
It denoted that schizophrenic brain has fewer malleable neural-networks in the left fronto-temporal area.

In conclusion, auditory hallucinations \& emotional process in schizophrenia appear to be foundation on corresponding neural networks, in which the training seems to occupy an essential role. Remarkably, targeting the training has been shown to decrease the intensity of hallucination

These outcomes show that facial handling competence is significantly decreased in schizophrenia. Patients with schizophrenia may have specific inadequacy in indulgence negative faces, \& negative symptoms may affect conclusion \& analyze parameter. 
Razafimandim

by A et al.

Zou MY

(2018)
Investigating the input of emotional skill,

Tso F I et al. (2010)

\begin{tabular}{|c|c|}
\hline & Examined the neural \\
\hline & activity under two \\
\hline & First condition is to \\
\hline & examine neural base \\
\hline & while producing \\
\hline & emotional sentences. \\
\hline & Second condition is to \\
\hline & examine neural base \\
\hline & while producing \\
\hline & $\begin{array}{l}\text { grammatical } \\
\text { composition }\end{array}$ \\
\hline
\end{tabular}

Administrate deposit of checklists cover different aspect including emotional expression and regulation, experiential pleasure plus assessing anhedonia, depressive symptoms \& negative symptoms.
Thirty nine patients

from outpatient's

clinic accidentally

allocated to three

groups intervention.

First group involve

training on facial

affect recognition,

Second group involve

training on

attention-training,

third group involve

treatment as usual.

Noticing that twenty

four healthy subject

harmonized for

oldness and schooling,

were allocated to one

of the two

interventions.

twenty one patients

and twenty five

corresponding subject

undergo

magnetic resonance

imaging prototype

include two tasks:

First condition is to

examine neural base

while producing

emotional sentences.

Second condition is to

examine neural base

while producing

grammatical

composition

Subject of study included one hundred

forty six in-patients with schizophrenia versus seventy three corresponding group.
Patients and corresponding group show signs of good quality inner dependability on all self-report measures, except for negative
Descriptive correlation affect severity. Patients describe evenly intense but fewer frequent positive emotions, more intense and frequent negative emotions, and additional anhedonia

1-patients response period throughout the emotion ascription Assignment.

2-Patients demonstrate decrease of stimulation in

descriptive study two-sided auditory areas nevertheless of the presence of emotions. 3-during emotional sentences ascription, patients demonstrate fewer triggering in the cortex praefrontalis.

Results show three-groups group 1 differentiate by a shortage in experiential enjoyment and emotional regulation, Cluster 2 differentiate

descriptive study by a universal shortage in experiential enjoyment, emotional parameter and emotion expression, and group 3

differentiate by a shortage in emotion expression. demonstrate elongated
Study found improved in affect recognition training group following the intervention targeting FAR this progress was marked more in terror recognition. Furtherm ore neurocognition and social cognition, emotional experience made exclusive outcome in schizophrenia. influences to social
Abnormality observed in the $\mathrm{m}$ PFC during the emotion ascription assignment could give a biological foundation for social cognition insufficiency in patients with schizophrenia mainly in the cortex praefrontalis while producing emotional sentences.
Patients in group one displayed Inadequate reassessment approaches. those in group two displayed Inadequate reassessment and unnecessary repression; while those in group three displayed extreme suppression aggravating factors in to faulty of emotion control. 


\begin{tabular}{|c|c|c|c|c|c|}
\hline \multirow{12}{*}{$\begin{array}{l}\text { Edit Vass et } \\
\text { al. (2018) }\end{array}$} & \multirow{12}{*}{$\begin{array}{l}\text { Compare interference } \\
\text { methods in sequence } \\
\text { to observe how } \\
\text { efficient they are in } \\
\text { the remediation of } \\
\text { ToM, and to discover } \\
\text { the most excellent } \\
\text { techniques to improve } \\
\text { deficits in } \\
\text { schizophrenic } \\
\text { patient's cognitive } \\
\text { function. }\end{array}$} & \multirow{12}{*}{$\begin{array}{l}\text { Discover the most } \\
\text { excellent techniques to } \\
\text { improve deficits in } \\
\text { schizophrenic } \\
\text { patient's cognitive } \\
\text { function }\end{array}$} & & \multirow{12}{*}{$\begin{array}{l}\text { According to findings } \\
\text { targeted ToM } \\
\text { intervention produced } \\
\text { more advance in ToM } \\
\text { tasks, while data } \\
\text { regarding non-ToM } \\
\text { interventions showed } \\
\text { opposing } \\
\text { consequences with } \\
\text { restricted effects on } \\
\text { ToM }\end{array}$} & \multirow{12}{*}{$\begin{array}{l}\text { Targeted ToM } \\
\text { intervention is intendec } \\
\text { to advance the patients' } \\
\text { skill to attribute mental } \\
\text { states to others. } \\
\text { They employ scenarios, } \\
\text { comic strip assignment } \\
\text { or short video scene as } \\
\text { teaching resources to } \\
\text { nearby social } \\
\text { interactions, where the } \\
\text { patients are requested } \\
\text { to recognize and } \\
\text { examine the characters' } \\
\text { mental states }\end{array}$} \\
\hline & & & & & \\
\hline & & & & & \\
\hline & & & & & \\
\hline & & & & & \\
\hline & & & descrintive study & & \\
\hline & & & aescriptive study & & \\
\hline & & & & & \\
\hline & & & & & \\
\hline & & & & & \\
\hline & & & & & \\
\hline & & & & & \\
\hline
\end{tabular}

examine neural base while producing emotional sentences. Second condition is to examine neural base while producing grammatical composition [7]. Results shows irregularity observed in cortex praefrontalis while producing passionate sentences. This indicates an organic origin for social cognition insufficiency in schizophrenic persons. In general, many studies revealed abnormality in neural activity in schizophrenia using theory of mind tasks.

From another aspect Vogel B et al. (2016) investigates the ability of the patients to associate between both verbal \& nonverbal cues [8]. Different video shows were offered to twenty one patients versus 21 control subject. Results indicate that patients be inclined to stand their choice fewer on expressions cues and depend more on verbal statement than matched group.

There was much focus from research on emotional processing as one of essential elements of social cognition. Tabak, N. T et al. (2015) examined emotional intelligence (EI) trait in manic and schizophrenic patients versus corresponding control group. The purpose of study was to examine emotional intelligence trait \& its relation to clinical and social factors among studied groups [9]. Results reveal that both clinical groups show considerable poorer perceived emotional intelligence trait than corresponding group, but did not change from each other. Higher total emotional intelligence traits associated with elevated levels of self-governing living in both groups. The result proposed that emotional intelligence disturbance affecting community functioning in both groups.

Moreover, Zou MY (2018) administrate deposit of checklists cover different aspect of emotional processing including emotional expression and regulation, experiential pleasure plus assessing anhedonia, depressive symptoms \& negative symptoms. Subject of study included one hundred forty six in-patients with schizophrenia versus seventy three corresponding group. Results show three-groups. Group 1 differentiate by a shortage in experiential enjoyment and emotional regulation, group 2 differentiate by a universal shortage in experiential enjoyment, emotional regulation and emotion expression, and group 3 differentiate by a shortage in emotion expression [10]. literature study was done by 
Fiszdon, J. M., \& Reddy, L. F. (2012) which target social cognitive interventions in schizophrenia, finding indicate that there was a variety of interference have be initiated to target ToM, affect recognition, social perception, affect recognition but there is no attempt have particularly embattled ascription bias, emotional intelligence or social knowledge [1].

Edit Vass et al. (2018) compare intervention method to observe to what extent useful they are in the remediation of ToM, and to find the best techniques to ameliorate ToM deficits in schizophrenia. Findings indicating that best interference was that directed ToM, produce more advance in ToM tasks [11].

Vita et al. (2018) provide more information about various drugs enhancing neuroplasticity for schizophrenia alongside with intervention targeted social cognitive deficit. Second Generation Antipsychotics (SGAs) stated to be partially improving cognitive dysfunction, due to their relatively high attraction for serotonin 5HT2A receptors. Dysfunction of Geaba led to cognitive insufficiencies. The properties of Geaba produce improvement on cognition of a group of amino acids that act as glutamate agonists by tie to the glycyl site on The $\mathrm{N}$-methyl-D-aspartate receptor receptors.

It was discovered that the administration of muscarinic antagonists potentiated the cognitive impairments, and the $\alpha 7$ nicotinic acetylcholine receptors have been shown to play an important role in cognition with potential therapeutic effect in schizophrenia. A number of studies regarding drugs targeting neuroinflammation and oxidative stress to advance cognitive deficits appeared [12].

Furthermore, a lot of researchers attempt to address relation between elements of social cognition and social function among patients. For example, Lehmann A et al. (2014) investigate empathy, inner experience of emotion, emotional contagion among 55 with paranoid schizophrenia versus fifty five control subject using Interpersonal Reactivity Index, Experience of Emotions and Emotional Contagion tools. Finding indicate that patients have considerably more negative emotional contagion, devastating feelings, deficiency in feelings, and imagination capacity than control group [13].

Whereas, Ahmeda $\mathrm{OH}$ (2018) investigate the relation between aggression traits \& cognitive impairment taken into consideration how negative emotions affect cognitive deficit. They found that cognitive insufficiency raise the liability of reckless violence in schizophrenia by means of incompetent control of negative emotional condition [14].

Ferrara et al. (2012) investigated literature for the association between emotional processing insufficiency and hallucinations mainly auditory verbal $(\mathrm{AVH})$. The relation between hallucination and emotional prosody understanding has stayed inspected among schizophrenicpatients. Results of researches are contrary a number of inquiries did not discover a relation involving emotional process deficits \& hallucinations. While others indicate presence of relation. Author concluded that auditory hallucinations \& emotional process in schizophrenia appear to be foundation on corresponding neural networks, in which 
the training seems to occupy an essential role. Remarkably, targeting the training has been shown to decrease the intensity of hallucination [15].

\section{- PART II: INTERVENTION STUDIES (Table 2)}

Fifteen intervention studies were drawn in this review. It was found that most of provided intervention was targeting emotions \& affect recognition training. For example, Sachs, G et al. (2012) investigates the impact of an affect recognition computer-based training on recognizing of different emotions \& on patients' life feature \& quality. Training sessions on recognizing emotions was employed. An assessment was done before \& after intervention regarding recognizing of different emotions, patients' life quality and clinical condition. Results show considerable progress especially in recognize gloomy expressions and, in addition, in the excellence of life area societal joining [16].

Moreover, Drusch K et al. (2014) examined the effect of emotions recognition teaching on emotions recognition by calculating numbers of right response \& eye look behavior (amount $\&$ period of fixation into salient or non-salient facial regions) was assessed using $2 \times 2$-design 16 patients \& sixteen corresponding group carry out a facial affect recognition task .Results showed that at beginning patients demonstrate fewer facial affect recognition than matched group but after training session they was be better [17]. The same findings have been replicated by Bechi et al. (2012) and Prova et al. (2014) [3].

Tsotsia S et al. (2017) randomly assigned thirty nine patients from outpatient's clinic in three groups intervention. First group involve training on facial affect recognition, Second group involve training on attention-training, third group involve treatment as usual. Noticing that twenty four healthy subject harmonized for oldness and schooling, were distributed to one of the two interventions. Study found improved in affect recognition training group following the intervention targeting Facial Affect Recognition (FAR) this progress was marked more in terror recognition [18].

Others researches focus on Emotion management skills. For example Won, M et al. (2012) implement Emotion management training program for I hour per week for sum of 2 months. The statistics were gathered from twenty two patients in intervention group \& thirty subjects in corresponding group [4].

Patients undergoing training session demonstrate a considerable distinction in interpersonal relationship, emotional expression, emotional behavior and social behavior scores than those in the corresponding group. Thus this program indicates its efficiency with schizophrenic patients, and it serving as an evidence-based nursing practice.

Wang Y et al. (2013) examined the clinical utility of Social Cognition and Interaction Training (SCIT) in patients with schizophrenia, treatment was done for twenty weeks. Patients received the SCIT interference \& usual treatment-. Attributional Style Questionnaire, Emotion Identification Task, Social Performance Scale, Chinese versions of the Personal and (PSP), Face (FEIT), Eyes task, and (ASQ) were given before \& after intervention. Results showed a considerable 
Table 2. Summary of intervention studies.

\begin{tabular}{|c|c|c|c|c|c|}
\hline $\begin{array}{l}\text { STUDY } \\
\text { AUTHORS }\end{array}$ & $\begin{array}{l}\text { APPLICATION OF } \\
\text { TREATMENT }\end{array}$ & $\begin{array}{c}\text { INTERFERENCE } \\
\text { METHOD }\end{array}$ & $\begin{array}{l}\text { SAMPLE/ } \\
\text { DESIGN }\end{array}$ & $\begin{array}{l}\text { SIGNIFICANT } \\
\text { FINDING }\end{array}$ & $\begin{array}{c}\text { OTHER } \\
\text { OUTCOMES/NOTES }\end{array}$ \\
\hline $\begin{array}{l}\text { Won, M et al. } \\
2012\end{array}$ & $\begin{array}{l}\text { Emotion } \\
\text { management skills }\end{array}$ & $\begin{array}{l}\text { I hour training on } \\
\text { emotion management } \\
\text { has. been applied for } 2 \\
\text { months }\end{array}$ & $\begin{array}{l}\text { The statistics were } \\
\text { gathered from } \\
\text { twenty two } \\
\text { patients in } \\
\text { intervention } \\
\text { group \&thirty in } \\
\text { corresponding } \\
\text { group }\end{array}$ & $\begin{array}{l}\text { The intervention } \\
\text { cluster } \\
\text { demonstrate } \\
\text { a considerable } \\
\text { distinction in } \\
\text { social relationship } \\
\text { scores, emotional } \\
\text { behavior \& } \\
\text { expression and } \\
\text { social behavior } \\
\text { scores } \\
\text { than those in } \\
\text { the corresponding } \\
\text { group. }\end{array}$ & $\begin{array}{l}\text { I hour training on } \\
\text { emotion management } \\
\text { for schizophrenic } \\
\text { patients serving as } \\
\text { resourceful } \\
\text { evidence-based care to } \\
\text { the patients during the } \\
\text { course of intervention }\end{array}$ \\
\hline $\begin{array}{l}\text { Sachs, G et al. } \\
(2012)\end{array}$ & $\begin{array}{l}\text { Study the effects } \\
\text { of a on affect } \\
\text { recognition (TAR) } \\
\text { computer-based } \\
\text { training of emotion } \\
\text { recognition and } \\
\text { mainly on life } \\
\text { quality \& features }\end{array}$ & $\begin{array}{l}1.5 \text { month teaching on } \\
\text { emotions recognizing }\end{array}$ & $\begin{array}{l}\text { prior \& after } \\
\text { intervention } \\
\text { evaluation of } \\
\text { affect recognizing } \\
\text { life quality, } \\
\text { cognition, and } \\
\text { symptoms } \\
\text { presentation } \\
\text { were examined }\end{array}$ & $\begin{array}{l}\text { An assessment } \\
\text { was done before \& } \\
\text { after intervention } \\
\text { regarding } \\
\text { recognizing of } \\
\text { different } \\
\text { emotions, } \\
\text { patients' life } \\
\text { quality } \\
\text { and clinical } \\
\text { condition. } \\
\text { Results show } \\
\text { considerable } \\
\text { progress especially } \\
\text { in recognize } \\
\text { gloomy faces and, } \\
\text { in addition, in the } \\
\text { quality of } \\
\text { life area social } \\
\text { connection. }\end{array}$ & $\begin{array}{l}\text { The result sustain the } \\
\text { effectiveness of emotion } \\
\text { recognition teaching for } \\
\text { clients with } \\
\text { schizophrenia \& the } \\
\text { generality to societal } \\
\text { connection }\end{array}$ \\
\hline $\begin{array}{l}\text { Peters MJ } \\
(2013)\end{array}$ & $\begin{array}{l}\text { Examined effect of } \\
\text { emotionality on } \\
\text { remembrance and } \\
\text { meta-memory by } \\
\text { means of videotape } \\
\text { succession }\end{array}$ & $\begin{array}{l}27 \text { clients and twenty } \\
\text { four corresponding } \\
\text { were given a recently } \\
\text { created emotional } \\
\text { videotape prototype } \\
\text { with } 5 \text { diverse } \\
\text { emotions including } \\
\text { negative, positive, } \\
\text { neutral and } \\
\text { delusional themes. }\end{array}$ & $\begin{array}{l}\text { pre- and } \\
\text { post-treatment } \\
\text { assessments }\end{array}$ & $\begin{array}{l}\text { Following } \\
\text { watching video, } \\
\text { subject rating } \\
\text { their confidence, } \\
\text { naming emotions } \\
\text { to create their } \\
\text { judgment along } \\
\text { with ratings, } \\
\text { examine } \\
\text { remembrance } \\
\text { correctness and } \\
\text { meta-memory } \\
\text { insufficiency in } \\
\text { more interacting } \\
\text { context }\end{array}$ & $\begin{array}{l}\text { Almost all patients } \\
\text { confidently valenced } \\
\text { video, patients } \\
\text { recognized less right } \\
\text { items contrast to } \\
\text { corresponding subject, } \\
\text { and did not vary with } \\
\text { regard to the amount } \\
\text { of false memories for } \\
\text { related items. }\end{array}$ \\
\hline
\end{tabular}




\section{Continued}

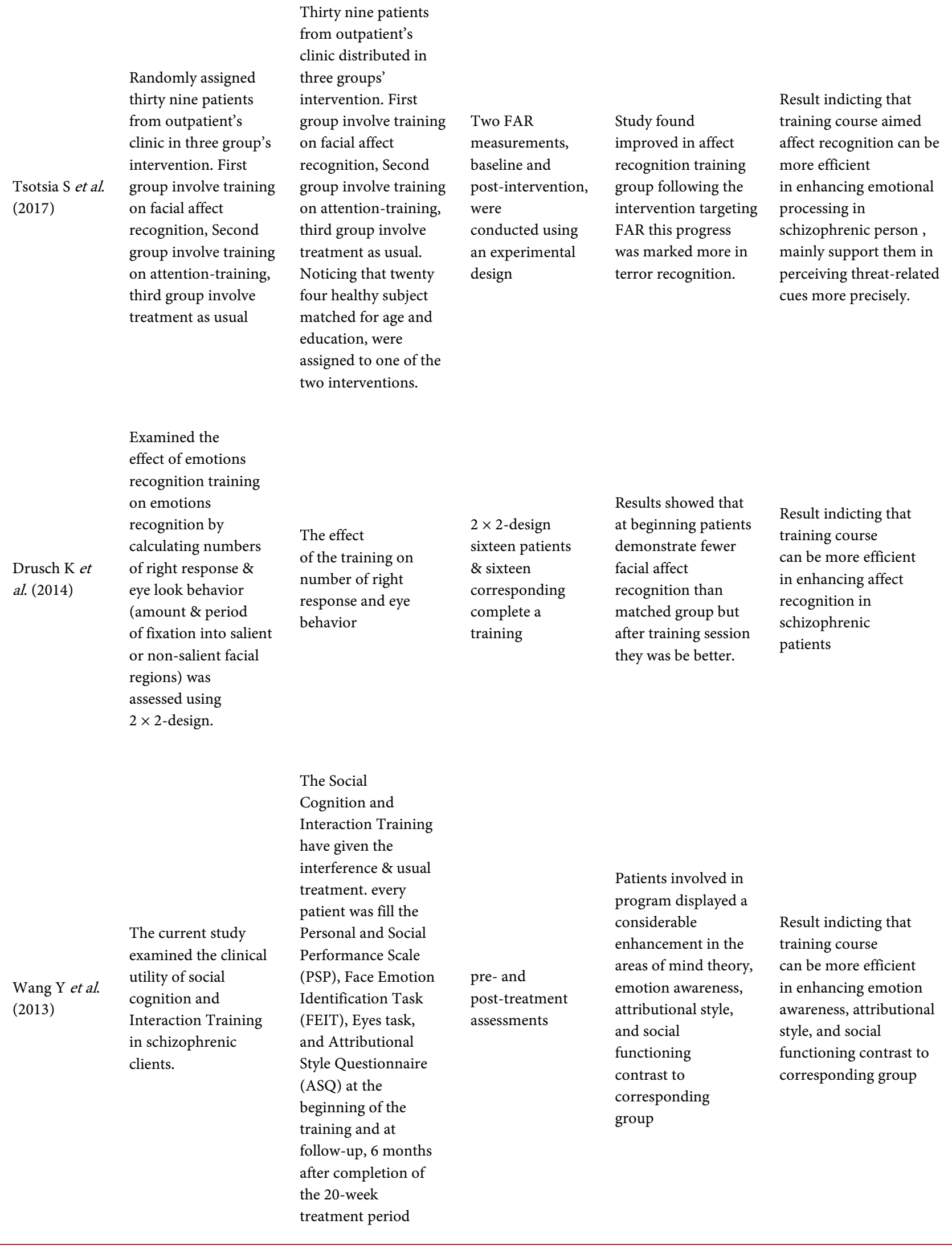




\begin{tabular}{|c|c|c|c|c|c|}
\hline $\begin{array}{l}\text { Campo VM } \\
(2016)\end{array}$ & $\begin{array}{l}\text { Examined } \\
21 \text { schizophrenia } \\
\text { patients whereby } \\
\text { patients were involved } \\
\text { in experimental group } \\
\text { and nine in the } \\
\text { corresponding group. } \\
\text { Corresponding group } \\
\text { was given typical } \\
\text { treatment leisure \& } \\
\text { occupational therapy. } \\
\text { The experimental } \\
\text { group established } \\
\text { usual treatment in } \\
\text { addition to twelve } \\
\text { session (60 minutes } \\
\text { per week) as well as } \\
\text { education element on } \\
\text { emotional awareness } \\
\text { and a short lively } \\
\text { cartoon for mind } \\
\text { theory and attribution } \\
\text { style training, plus } \\
\text { computerized } \\
\text { metacognitive } \\
\text { feedback }\end{array}$ & $\begin{array}{l}\text { The intervention } \\
\text { group } \\
\text { received usual } \\
\text { treatment in addition } \\
\text { one and half month } \\
\text { training session on } \\
\text { emotional perception } \\
\text { and a short lively } \\
\text { cartoon, attribution } \\
\text { style, mind theory \& } \\
\text { metacognitive } \\
\text { feedback. }\end{array}$ & $\begin{array}{l}\text { pre/post } \\
\text { intervention } \\
\text { pilot study was } \\
\text { conducted }\end{array}$ & $\begin{array}{l}\text { For the studied } \\
\text { subject. After the } \\
\text { Training, statistically } \\
\text { considerable results } \\
\text { were obtained for EP } \\
\text { (Ekman } 60 \text { Faces } \\
\text { Test), ToM (Hinting } \\
\text { Task, Faux Pas, } \\
\text { Happé), AS } \\
\text { (Ambiguous } \\
\text { Intentions Hostility } \\
\text { Questionnaire). }\end{array}$ & $\begin{array}{l}\text { Result indicting that } \\
\text { training course can be } \\
\text { more efficient in } \\
\text { enhancing on } \\
\text { emotional perception, } \\
\text { attribution style, mind } \\
\text { theory \& metacognitive } \\
\text { feedback. }\end{array}$ \\
\hline
\end{tabular}

progress in the areas of mind theory, attribution style, emotion perception, and social functioning compared to corresponding group [19].

While Peters MJ (2013) examined the effect of emotional training by using different video scenarios where by subjects given 5 different emotions including 2 negative, 1 neutral, one positive, and one delusional theme [20]. Following watching video, subject rating their confidence, naming emotions to create their judgment along with ratings, examine remembrance correctness and meta-memory insufficiency in more interacting context. Almost all patients confidently valenced video, patients recognized less right items contrast to corresponding subject, and did not vary with regard to the amount of false memories for related items.

Campo VM (2016) examined schizophrenia patients whereby 21 patients were involved in experimental group and nine in the corresponding group. Corresponding group was given typical treatment leisure \& occupational therapy. The experimental group established usual treatment in addition to twelve session (60 minutes per week) as well as education element on emotional awareness and a short lively cartoon for mind theory and attribution style training, plus computerized metacognitive feedback. Endpoints: EP (Ekman 60 Faces Test), ToM (Hinting Task, Faux Pas, Happé), AS (Ambiguous Intentions Hostility Questionnaire). Following the interference, statistically considerable data were obtained for the EP, ToM and AS variables. Group reflect on the intervention plus treatment-as-usual. All patients were fill the Chinese forms of the Personal and 
Social Performance Scale (PSP), Face Emotion Identification Task (FEIT), Eyes task, and Attributional Style Questionnaire (ASQ) at baseline of the social cognitive intervention treatment period and at follow-up, 6 months after completion of the 20-week treatment period [2].

Tso F I et al. (2010) investigated the input of emotional skill, social cognition \& neurocognition in functional outcome of schizophrenia. Thirty nine patients from outpatient's clinic accidentally allocated to three groups intervention. First group involve training on facial affect recognition, second group involve training on attention-training, third group involve treatment as usual. Noticing that twenty four healthy subject harmonized for oldness and schooling, were allocated to one of the two interventions. Descriptive correlation patients and corresponding group show signs of good quality inner dependability on all self-report measures, except for negative affect severity. Patients describe evenly intense but fewer frequent positive emotions, more intense and frequent negative emotions, and additional anhedonia Study found improved in affect recognition training group following the intervention targeting FAR this progress was marked more in terror recognition. Furthermore, neurocognition and social cognition, emotional experience made exclusive influences to social outcome inschizophrenia [21].

Regarding attribution style, most of studies found no effect of social cognitive interventions on attribution style [22] [23] [24] [25] [26]. However, Wangs et al. 2013 found that patients in social cognitive intervention group showed a considerable enhancement in the areas of emotion perception, theory of mind, attributional style, and social functioning compared to control group. The same was reported previously by Horan et al. (2011) [23].

\section{Discussion \& Conclusion}

In conclusion inquiry today has recognized that some social cognitive fields are responsive to planned teaching, and a great deal of work is still needed to be done, improving their effects on more complex social cognitive areas, to examine its effects as well as their extending to significant societal performance and also in enhancing neuroplasticity.

This review indicates the efficacy of social intervention that targets cognitive aspect and functional abilities of schizophrenic patients; and that effect perception is flexible and can be managed. Medications can properly modify neurochemical discrepancies that trigger neuroplasticity alterations in the brain, whereas cognitive training may induce the creation of more adaptive neural circuits. Emotion processing is significant mediators of social performance aptitudes in schizophrenia; variables such as social cognition deficit which limit patient ability in integrative capacity for verbal and non-verbal cues should be considered during management plan. This means that higher levels of social cognition are associated with better functioning in schizophrenia and that social cognition might have a specific impact in neurocognition; the same was indicated by many studies [26] [27] [28]. 


\section{Clinical Implications}

While social cognition intervention that target cognitive aspect and functional abilities of schizophrenic patients should be generally considered during management to create more adaptive neural circuits this can includes medications that can properly modify neurochemical discrepancies and trigger neuroplasticity alterations in the brain, emotion processing training, considering limited patient ability in integrative capacity for verbal and non-verbal cues.

\section{Limitation of This Review}

These review only emphases somewhat on predictive social cognitive factors that may be involved in outcome and recovery. The lack of uniform methods among long-term outcome studies limits generalizations regarding the difference between current outcomes and outcomes proceeding to the initiation of current management.

\section{Further Research}

Further researches is needed to assess effect and durability of applying social cognitive intervention on neuroplasticity taken into consideration patients subjective experience upon this intervention, symptoms severity and period of follow up.

\section{Conflicts of Interest}

The authors declare no conflicts of interest regarding the publication of this paper.

\section{References}

[1] Fiszdon, J.M. and Reddy, L.F. (2012) Review of Social Cognitive Treatments for Psychosis. Clinical Psychology Review, 32, 724-740.

https://doi.org/10.1016/j.cpr.2012.09.003

[2] Campo, V.M., Maroño, Y., Lahera, G., Mateos, R. and García-Caballero, A. (2016) E-Motional Training ${ }^{\oplus}$ : Pilot Study on a Novel Online Training Program on Social Cognition for Patients with Schizophrenia. Schizophrenia Research: Cognition, 4, 10-17. https://doi.org/10.1016/j.scog.2015.11.007

[3] Bechi, M., Riccaboni, R., Ali, S., Fresi, F., Buonocore, M., Bosia, M. and Cavallaro, R. (2012) Theory of Mind and Emotion Processing Training for Patients with Schizophrenia: Preliminary Findings. Psychiatry Research, 198, 371-377. https://doi.org/10.1016/j.psychres.2012.02.004

[4] Won, M., Lee, K., Lee, J. and Choi, Y. (2012) Effects of an Emotion Management Nursing Program for Patients with Schizophrenia. Archives of Psychiatric Nursing, 26, 54-62. https://doi.org/10.1016/j.apnu.2011.02.006

[5] Zhua, L.X., Tana, P.S., Yanga, D.F., Sunb, W., Songa, S.C., Cuia, F.J., Zhaoa, L.Y., Fana, M.F., Lia, J.Y., Tana, L.Y. and Zoua, Z.Y. (2013) Visual Scanning of Emotional Faces in Schizophrenia. Neuroscience Letters, 552, 46-51. https://doi.org/10.1016/j.neulet.2013.07.046

[6] Akara, S.A., Karaa, S., Glub, F.L. and Bilgiçc, V. (2015) Estimation of Nonlinear 
Measures of Schizophrenia Patients EEG in Emotional States. IRBM, 36, 250-258. https://doi.org/10.1016/j.irbm.2015.06.005

[7] Razafimandimby, A., Hervé, Y.P., Marzloff, V., Brazo, P., Tzourio-Mazoyer, N. and Dollfus, S. (2016) Functional Deficit of the Medial Prefrontal Cortex during Emotional Sentence Attribution in Schizophrenia. Schizophrenia Research, 178, 86-93. https://doi.org/10.1016/j.schres.2016.09.004

[8] Vogel, B., Carolin Heike Jacob, B., Eberle, M. and Wildgruber, D. (2016) Integration of Verbal and Nonverbal Emotional Signals in Patients with Schizophrenia: Decreased Nonverbal Dominance. Psychiatry Research, 241, 98-103. https://doi.org/10.1016/j.psychres.2016.03.050

[9] Tabak, N.T., Green, M.F., Wynn, J.K., Proud, G.H., Altshuler, L. and Horan, W.P. (2015) Perceived Emotional Intelligence Is Impaired and Associated with Poor Community Functioning in Schizophrenia and Bipolar Disorder. Schizophrenia Research, 162, 189-195. https://doi.org/10.1016/j.schres.2014.12.005

[10] Zou, M.Y., Ni, K., Yang, Y.Z., Li, Y., Cai, L.X., Xie, J.D., Zhang, T.R., Zhou, C.F., Li, X.W., Lui, S.Y., Shuma, H.K., Cheung, F.C. and Chan, C.K. (2018) Profiling of Experiential Pleasure, Emotional Regulation and Emotion Expression in Patients with Schizophrenia. Schizophrenia Research, 195, 396-401.

https://doi.org/10.1016/j.schres.2017.08.048

[11] Vass, E., Fekete, Z., Simon, V. and Simon, L. (2018) Interventions for the Treatment of Theory of Mind Deficits in Schizophrenia: Systematic Literature Review. Psychiatry Research, 267, 37-47. https://doi.org/10.1016/j.psychres.2018.05.001

[12] Vita, A., Mussoni, C., Deste, G., Ferlenghi, G., Turrina, C. and Valsecchi, P. (2018) Psychopharmacological Treatment of Cognitive Deficits in Schizophrenia and Mood Disorders. Journal of Psychopathology, 24, 62-72.

[13] Lehmann, A., Bahçesular, K., Brockmann, E.M., Biederbick, S.E., Dziobek, I., Gallinat, J. and Montag, C. (2014) Subjective Experience of Emotions and Emotional Empathy in Paranoid Schizophrenia. Psychiatry Research, 220, 825-833. https://doi.org/10.1016/j.psychres.2014.09.009

[14] Ahmeda, O.H., Richardsonb, J., Bucknera, A., Romanoffc, S., Federc, M., Oragunyea, N., Ilnickia, A., Bhatd, I., Hoptmane, M.J. and Lindenmayere, P.J. (2018) Do Cognitive Deficits Predict Negative Emotionality and Aggression in Schizophrenia? Psychiatry Research, 259, 350-357.

[15] Ferrara, A.L., Fernyhough, C., Weis, S., Mitchell, C.R. and Hausmann, M. (2012) Contributions of Emotional Prosody Comprehension Deficits to the Formation of Auditory Verbal Hallucinations in Schizophrenia. Clinical Psychology Review, 32, 244-250. https://doi.org/10.1016/j.cpr.2012.02.003

[16] Sachs, G., Winklbaur, B., Jagsch, R., Lasser, I., Kryspin-Exner, I., Frommann, N. and Wölwer, W. (2012) Training of Affect Recognition (TAR) in Schizophrenia-Impact on Functional Outcome. Schizophrenia Research, 138, 262-267. https://doi.org/10.1016/j.schres.2012.03.005

[17] Drusch, K., Stroth, S., Kamp, D., Frommann, N. and Wölwer, W. (2014) Effects of Training of Affect Recognition on the Recognition and Visual Exploration of Emotional Faces in Schizophrenia. Schizophrenia Research, 159, 485-490. https://doi.org/10.1016/j.schres.2014.09.003

[18] Tsotsia, S., Kosmidisa, M.H. and Bozikasb, V.P. (2017) Improved Facial Affect Recognition in Schizophrenia Following an Emotion Intervention, but Not Training Attention-to-Facial-Features or Treatment-as-Usual. Psychiatry Research, 254, 135-142. https://doi.org/10.1016/j.psychres.2017.04.038 
[19] Wang, Y., David, L., Roberts, L.D., Xu, B., Cao, R., Yan, M. and Jiang, Q. (2013) Social Cognition and Interaction Training for Patients with Stable Schizophrenia in Chinese Community Settings. Psychiatry Research, 210, 751-755. https://doi.org/10.1016/j.psychres.2013.08.038

[20] Peters, M.J., Hauschildt, M., Moritz, S. and Jelinek, L. (2013) Impact of Emotionality on Memory and Meta-Memory in Schizophrenia Using Video Sequences. Journal of Behavior Therapy and Experimental Psychiatry, 44, 77-83.

https://doi.org/10.1016/j.jbtep.2012.07.003

[21] Tso, F.I., Tyler, B., Grove, B.T. and Taylor, F.S. (2010) Emotional Experience Predicts Social Adjustment Independent of Neurocognition and Social Cognition in Schizophrenia. Schizophrenia Research, 122, 156-163.

https://doi.org/10.1016/j.schres.2009.12.007

[22] Horan, W.P., Kern, R.S., Shokat-Fadai, K., Sergi, M.J., Wynn, J.K. and Green, M.F. (2009) Social Cognitive Skills Training in Schizophrenia: An Initial Efficacy Study of Stabilized Outpatients. Schizophrenia Research, 107, 47-54. https://doi.org/10.1016/j.schres.2008.09.006

[23] Horan, W.P., Kern, R.S., Tripp, C., Hellemann, G., Wynn, J.K., Bell, M. and Green, M.F. (2011) Efficacy and Specificity of Social Cognitive Skills Training for Outpatients with Psychotic Disorders. Journal of Psychiatric Research, 45, 1113-1122. https://doi.org/10.1016/j.jpsychires.2011.01.015

[24] Roberts, D.L., Combs, D.R., Willoughby, M., Mintz, J., Gibson, C., Rupp, B. and Penn, D.L. (2014) A Randomized, Controlled Trial of Social Cognition and Interaction Training (SCIT) for Outpatients with Schizophrenia Spectrum Disorders. The British Journal of Clinical Psychology, 53, 281-298. https://doi.org/10.1111/bjc.12044

[25] Tas, C., Danaci, A.E., Cubukcuoglu, Z. and Brune, M. (2012) Impact of Family Involvement on Social Cognition Training in Clinically Stable Outpatients with Schizophrenia-A Randomized Pilot Study. Psychiatry Research, 195, 32-38. https://doi.org/10.1016/j.psychres.2011.07.031

[26] Sterea, R. (2015) The Relationship between Social Cognition and Functional Outcomes in Schizophrenia. Procedia Social and Behavioral Sciences, 187, 256-260. https://doi.org/10.1016/j.sbspro.2015.03.048

[27] Strauss, G., Granholm, E., Holden, J., Ruiz, I., Gold, J., Kelly, D. and Buchanan, R. (n.d.) The Effects of Combined Oxytocin and Cognitive Behavioral Social Skills Training on Social Cognition in Schizophrenia. Psychological Medicine, 1-9.

[28] Cavallaro, R., Bechi, M. and Spangaro, M. (2018) Targeting Social Cognition to Improve Functional Outcome of Patients with Schizophrenia: Clinical Evidences. Journal of Psychopathology, 24, 88-92. 